\title{
First Report of Pink Disease on Native Trees in South Africa and Phylogenetic Placement of Erythricium salmonicolor in the Homobasidiomycetes
}

\author{
J. Roux and M. P. A. Coetzee, Department of Genetics, DST/NRF Centre for Tree Health Biotechnology \& Tree \\ Protection Co-operative Programme (TPCP), Forestry and Agricultural Biotechnology Institute (FABI), University of \\ Pretoria, Pretoria, 0002, South Africa
}

\begin{abstract}
Roux, J., and Coetzee, M. P. A. 2005. First report of pink disease on native trees in South Africa and phylogenetic placement of Erythricium salmonicolor in the Homobasidiomycetes. Plant Dis. 89:1158-1163.

Erythricium salmonicolor causes a canker and die-back disease, commonly known as pink disease, on many tree species. During an investigation of diseases of Podocarpus henkellii and $P$. latifolius in the Mpumalanga Province of South Africa, typical symptoms of pink disease were observed on the branches of these trees. Stem and branch cankers covered with cracked bark and abundant pink mycelial growth were common on the affected trees. In subsequent surveys, the disease was also found on native Dais cotonifolia in the same area, as well as on native Ekebergia capensis and Maesa lanceolata in the KwaZulu-Natal Midlands. Phylogenetic analyses of ribosomal large subunit DNA sequence data were used to confirm the identity of the pathogen and obtain an indication of its phylogenetic placement within the Homobasidiomycetes. Isolates from all the native hosts recorded in this study, as well as from exotic Eucalyptus sp. and Acacia mearnsii, formed a strongly supported clade together with isolates from other parts of the world. Results confirmed that the pathogen in South Africa is Erythricium salmonicolor. Isolates from South Africa and Ethiopia grouped closely together, slightly different from E. salmonicolor isolates from the rest of the world. Our data also suggest that the genus name for E. salmonicolor possibly should be reconsidered because it groups separately from E. laetum or Corticium roseum. Phylogenetic analyses further indicated that the genus Erythricium is most closely related to Marchandiomyces aurantiacus, M. lignicola, C. roseum, E. laetum, Dendrothele maculata, D. roseacarneum, Vuilleminia comedens, V. macrospora, Punctularia strigoso-zonata and Galzinia incrustans. These genera form a separate subclade, the corticioid clade, within the Homobasidiomycetes. Pink disease is potentially important in South Africa because it affects a wide range of native and exotic tree species, and this study provides a foundation for further research.
\end{abstract}

Erythricium salmonicolor (Berk. \& Broome) Burdsall (syn. Corticium salmonicolor Berk. \& Broome, Phanerochaete salmonicolor (Berk. \& Broome) Jülich) is known from many countries with both tropical and temperate climates. It is especially well known for the disease commonly referred to as pink disease on rubber trees (Hevea brasiliensis) and Eucalyptus spp. in the tropics $(9,15,24)$. It has a very wide host range, including citrus (17), Casurina equisetifolia $(13,24)$, Theobraomae cacao $(9,24)$, Malus sp. $(4,17)$, and many other tree crops, including coffee, tea, and cashew $(9,24)$. In countries such as India, pink disease has been

Corresponding author: J. Roux

E-mail: jolanda.roux@fabi.up.ac.za

Financial support was provided by the Tree Protection Co-operative Programme (TPCP), especially SAFCOL, the National Research Foundation, and the THRIP initiative of the Department of Trade and Industry, South Africa.

Accepted for publication 30 April 2005.

DOI: 10.1094/PD-89-1158

(C) 2005 The American Phytopathological Society recorded from many forest trees, including both native and exotic species $(22,24)$.

Pink disease results in branch and stem die-back due to girdling cankers (9). Cankers are characterized by gum exudation and longitudinal splitting of the bark, developing as the cambium is killed (9). They often are covered with fungal mycelium which can occur in four stages (9). The earliest stage, known as the cobweb phase, is characterized by light white- to pink-colored mycelium. The pustular phase is characterized by erumpent masses of pink mycelium, appearing on any part of the canker, whereas the pink- or salmon-colored crustose phase develops mainly on the underside of branches. The fourth stage, known as the necator stage, is recognized by the formation of bright orange or red pustules, usually on the upper sides of branches (9).

E. salmonicolor is common in many African countries (9). In South Africa, it has been reported only three times (3). These reports were from Eucalyptus spp. in the KwaZulu-Natal Midlands (14), Malus spp. in the Free State and KwaZulu-Natal Provinces (4), and Acacia mearnsii de Wild in the KwaZulu-Natal Midlands (19).
The corticioid fungi (Corticiaceae s.1.) are broadly classified based on their resupinate basidiocarps. The taxonomy of this family, including E. salmonicolor, is confused, with genera within the family Corticiaceae grouping with several other families within the Homobasidiomycetes $(7,8,12)$. Substantial progress has been made in elucidating the phylogenies of the Homobasidiomycetes using analyses of sequence data, mostly from the nuclear large subunit (LSU) and mitochondrial DNA. Binder and Hibbett recognized eight discrete clades within the Homobasidiomycetes (1). This recently has been adjusted to 12 clades by Larsson et al. (12), who described additional clades based on a phylogenetic study that focused on corticioid fungi. Fungi in the family Corticiaceae and, thus, the family in which $E$. salmonicolor resides were, however, found in all clades, showing that this group is clearly paraphyletic $(1,8,12)$. However, a distinct clade containing coriticiod fungi and including E. laetum, the type species of this genus, was identified by Larsson et al. (12).

This study had multiple aims. We wished to confirm the identity of the pink disease pathogen in South Africa and obtain an indication of its phylogenetic relationship to other Erythricium isolates available on GenBank. The phylogenetic placement of E. salmonicolor has not yet been elucidated and, because the members of Corticiaceae are known to be paraphyletic $(1,12)$, we made use of DNA sequence data obtained from the nuclear ribosomal LSU to determine its taxonomic placement.

\section{MATERIALS AND METHODS}

Disease and isolates. During routine tree disease surveys in the Sabie area $\left(\mathrm{S} 25^{\circ}\right.$ 05', E30 ${ }^{\circ} 47^{\prime}$ ) of the Mpumalanga Province, dying branches and stems bearing distinct cankers covered by pink mycelium were noted on Podocarpus henkelii Stapf. This prompted more intensive surveys of these trees in this and other areas of South Africa. Diseased material subsequently was collected from several Podocarpus spp. and Dais cotonifolia L. from the Sabie area. Material was also collected from $P$. henkelii, Ekebergia capensis Sparrm., and Maesa lanceolata Forsk. from the Kwazulu-Natal Midlands, around the town of Howick (S26 57.61', E26 ${ }^{\circ}$ 45.29'). 
Isolations were made directly from fungal mycelium growing on the surface of bark cankers. This was most commonly from the pustular stage of growth of the suspected pathogen. Mycelium was transferred to a selective medium for the isolation of basidiomycetous fungi containing dichloran, benomyl, and streptomycin (26). Plates were incubated at room temperature $\left(20\right.$ to $\left.25^{\circ} \mathrm{C}\right)$ until the onset of fungal growth. Isolates then were subcultured onto malt extract agar (MEA) (2\% Biolab Malt extract and 1.5\% Biolab agar in $1,000 \mathrm{ml}$ of distilled water).

Additional isolates of Erythricium salmonicolor were obtained from the Centraalbureau voor Schimmelcultures (CBS167.82, CBS810.85) and from the Indian Type Culture Collection (ITCCF283) for comparisons based on DNA sequence data. Two isolates from exotic hosts were also included from Eucalyptus macarthurii Dean \& Maid. (CMW7130) and Acacia mearnsii (CMW9580) in South Africa (Table 1). All isolates used in this study are maintained in the culture collection (CMW) of the Forestry and Agricultural Biotechnology Institute (FABI), University of Pretoria, and representative isolates have also been deposited into the National Collection of Fungi (PREM), Pretoria, South Africa.

DNA isolation. All isolates used in DNA-based comparisons were grown on $2 \%$ MEA plates at $25^{\circ} \mathrm{C}$ until they were covered with mycelium. Mycelium was scraped directly from the surface of the agar and transferred to 1.5-ml Eppendorf tubes. DNA was isolated using the method described by Raeder and Broda (18). The DNA was resuspended in $100-\mu$ l sterile water and stored at $-20^{\circ} \mathrm{C}$.

Polymerase chain reaction amplification. Primers LROR (5'ACCCGCTGAACTTAAGC5') and LR11 (5'GCCAGTTATCCCTGTGGTAA' 3 ) were used to partially amplify the nuclear LSU RNA The polymerase chain reaction (PCR) reaction mixtures included Expand at 0.04 U/ $\mu$ l (High Fidelity PCR system; Roche Diagnostics GmbH, Mannheim, Germany), $0.2 \mathrm{mM}$ of each dNTP, $10 \times$ buffer (with $\mathrm{MgCl}_{2}$ ), an additional $1 \mathrm{mM} \mathrm{MgCl}_{2}, 0.3$ $\mathrm{mM}$ of each primer, and DNA at approximately $2 \mathrm{ng} / \mu \mathrm{l}$. PCR reaction conditions in $25 \mu \mathrm{l}$ total volumes were as follows: an initial denaturation step at $96^{\circ} \mathrm{C}$ for $1 \mathrm{~min}$, followed by 35 cycles of primer annealing at $55^{\circ} \mathrm{C}$ for $30 \mathrm{~s}$, elongation at $72^{\circ} \mathrm{C}$ for 1 min, and denaturation at $92^{\circ} \mathrm{C}$ for $1 \mathrm{~min}$. A final elongation step was included at $72^{\circ} \mathrm{C}$ for $5 \mathrm{~min}$. All PCR products were visualized on agarose gels (1\%) stained with ethidium bromide under UV illumination.

DNA sequencing. PCR products were purified prior to sequencing using the QIAquick PCR purification kit (QIAGEN, $\mathrm{GmbH}$, Hilden, Germany). The PCR products then were sequenced using the Big Dye Cycle Sequencing kit with Amplitaq
DNA polymerase, FS (Perkin-Elmer, Warrington, UK), according to the manufacturer's protocol, on an ABI PRISM 377 DNA Autosequencer (Perkin-Elmer). The LSU PCR amplicons were partially sequenced in both directions using primers LR0R and LR5 (5'TCCTGAGGGAAACTTCG'3). All sequences were analyzed with Sequence Navigator (version 1.0.1; Perkin-Elmer Applied Biosystems, Inc., Foster City, CA).

DNA sequence and phylogenetic analyses. Sequence data for the South African isolates were compared by means of a BLAST search with LSU sequences available in GenBank (National Centre for Biotechnology Information [NCBI] nucleotide database). This was done to obtain an indication of which organisms showed the highest similarity to the South African isolates.

An initial analysis was conducted to determine the position of the South African isolates within the 12 homobasidiomycete clades. The data matrix for this analysis was based on the exact data set, as provided by Larsson et al. (12), together with the Erythricium isolates used in the current study. A strict consensus tree was obtained from the most parsimonious trees generated from the data matrix in PAUP*25 following the procedure described by Larsson et al. (12).

A smaller data set (66 taxa) which contained four representative isolates from each of the 12 clades recognized by Larsson et al. (12) was generated after the initial analysis. Some additional isolates identified by BLAST searches to be most related to the South African isolates were also included for the final analysis. Most parsimonious trees were generated from the smaller dataset through a heuristic tree search algorithm with tree-bisectionreconnection (TBR) branch swapping. Starting trees were obtained using stepwise addition, taxa were added randomly (100 replicates) (6), MaxTrees was set to 100 , and the "MulTrees" option was in effect for the analysis. Gaps were treated as missing data. Dacrymyces stillatus (Dacrymycetales), Tremella mesenterica (Tremellales), Elmerina holophaea, and Auricularia mesenterica (Auriculariales) were included as outgroup taxa.

A neighbor-joining tree was generated in MEGA version 2.1 (11) from a data matrix that included the species within the corticioid clade. This analysis was done to indicate the differences between the Erythricium salmonicolor isolates. Distances among taxa were calculated using pairwise deletion of gaps and a Kimura two-parameter (10) nucleotide substitution model. The phylogram was not rooted.

\section{RESULTS}

Disease and isolates. Pink disease was identified from $P$. henkelii during a routine

Table 1. List of Erythricium salmonicolor isolates sequenced in the current study ${ }^{\mathrm{a}}$

\begin{tabular}{lllc}
\hline Isolate $^{\mathbf{b}}$ & \multicolumn{1}{c}{ Host } & \multicolumn{1}{c}{ Origin } & GenBank accession no. \\
\hline CMW7129 & Podocarpus sp. & South Africa & AY672679 \\
CMW7130 & Eucalyptus macarthurri & South Africa & AY672677 \\
CMW8602 (CBS167.82) & Pyrus communis & Sri Lanka & AY672682 \\
CMW8604 (CBS810.85) & Malus sylvestris & Brazil & AY672678 \\
CMW9502 (ITCCF283) & Malus sp. & Brazil & AY672683 \\
CMW9503 & Dais cotinifolia & South Africa & AY672681 \\
CMW9580 & Acacia mearnsii & South Africa & AY672680 \\
\hline
\end{tabular}

${ }^{a}$ All other sequence data used for comparative purposes and presented in Figures 2, 3, and 4 were obtained from GenBank and Larsson et al. (12).

${ }^{\mathrm{b}} \mathrm{CMW}$ numbers represent isolates housed in the culture collection of the Forestry and Agricultural Biotechnology Institute (FABI), South Africa, CBS represents isolates obtained from the Centraalburaeu voor Schimmelkultures, and ITCCF represents isolates from the Indian Type Culture Collection.

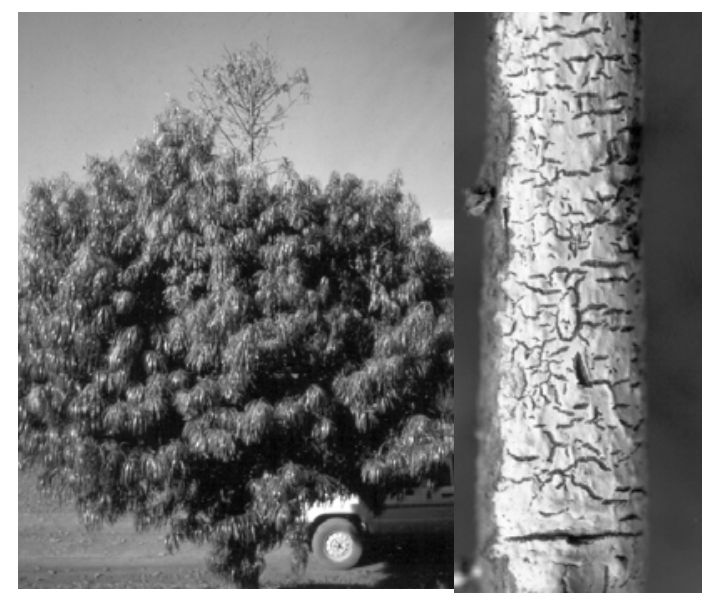

Fig. 1. Disease symptoms observed on Podocarpus sp.: left, branch and top death; right, pink mycelial growth on affected branch. 
disease survey at Tweefontein in the Sabie area (20). Subsequent surveys resulted in records of the disease from $P$. latifolius (Thumb.) R. Br. ex Mirb., P. falcatus (Thumb.) R. Br. ex Mirb. (Podocarpaceae), Dais cotinifolia (Thymelaeaceae), Ekebergia capensis (Meliaceae), Maesa lanceolata (Myrsinaceae), and Acacia mearnsii.

Disease symptoms were characterized initially by the death of single branches (Fig. 1), forming "red flags" of dead foliage within the otherwise green canopy of the trees. Closer examination revealed the presence of pink-, white-, or salmoncolored mycelial growth on the affected branches (Fig. 1). In some cases, more than one form of mycelial growth was found on a single branch or stem. The forms of mycelial growth could be characterized into several different growth types described for Erythricium salmonicolor, including a pustular phase characterized by discrete pustules of mycelium bursting through the bark of affected trees, a pink

\section{Consensus tree}

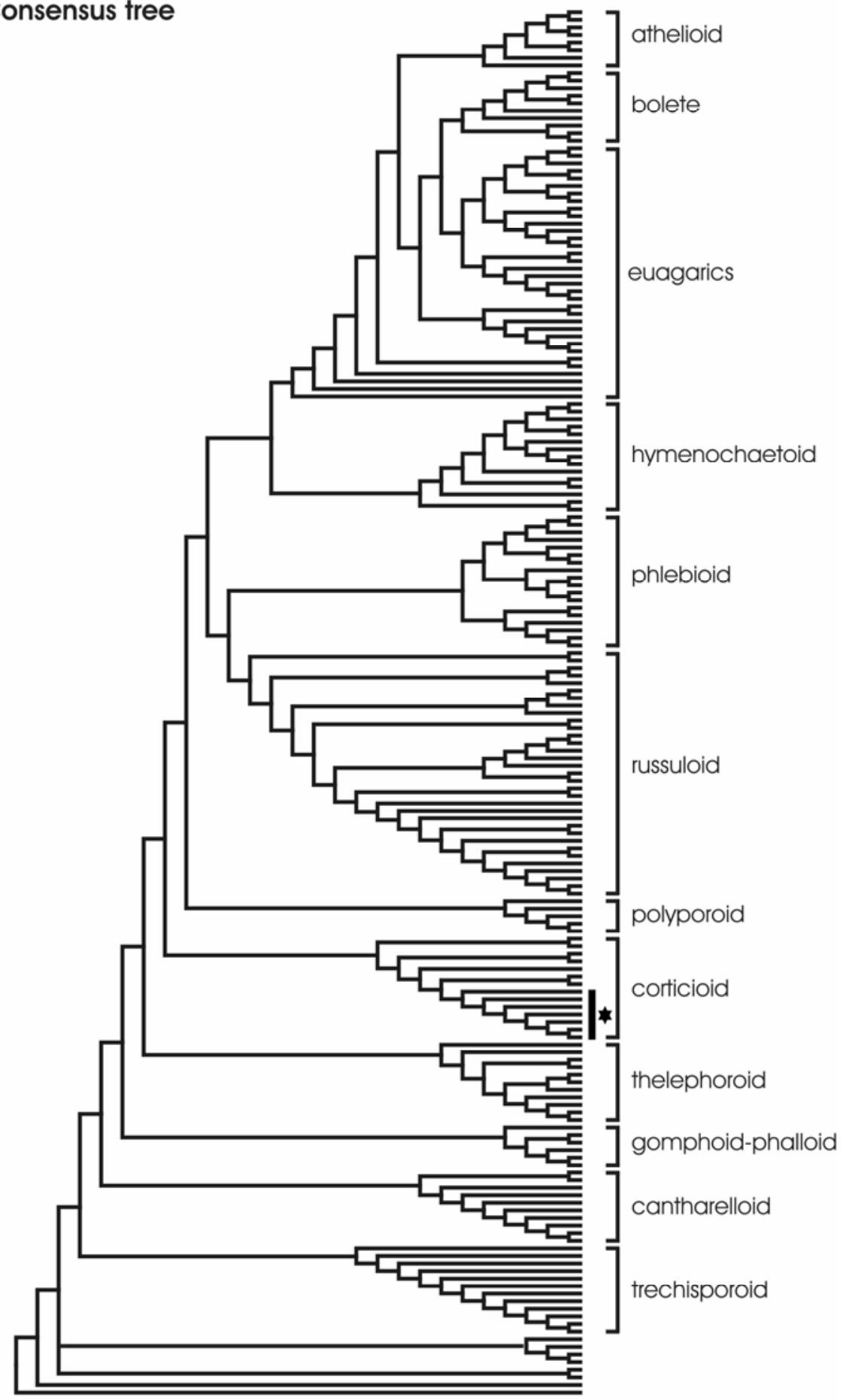

Fig. 2. Strict consensus tree generated from 5,800 MP trees produced after a heuristic search in PAUP*. The 12 named clades are those that have been defined for the Homobasidiomycetes by Larsson et al. (12). The position of the South African isolates is indicated by the star and bold line. crust of mycelium covering the affected tree part, or a fine white "cobweb" type of growth. In more advanced stages, the disease had spread from the branches to the main stem, where it produced girdling cankers. These cankers resulted in the death of the stems (Fig. 1).

The disease was found at three different sites around the town of Sabie (Frankfort Plantation, Tweefontein Plantation, and Horseshoe Falls), affecting ornamental trees as well as those planted in provenance trials and growing in natural forests. In the Kwazulu-Natal Midlands, pink disease was found on the two native species, P. henkelii and Ekebergia capensis, at two sites (Lions River and Karkloof) and on exotic A. mearnsii in the Karkloof area.

DNA sequencing and analyses. Blast searches of the LSU sequences indicated that the South African isolates are most similar to Erythricium salmonicolor (Corticiaceae) (AF506709) from Ethiopia. This was followed by Marchandiomyces aurantiacus (Lasch) Diederich \& Etayo (AY583330) (Ceratobasidiales), V. comedens (Corticiaceae) (AF518666), E. laetum (AY586655), G. incrustans (AF518617) (Corticiaceae), and Fomitopsis pinicola (AF287858) (Polyporaceae). The South African isolates showed a high sequence similarity ( 98.7 to $99.8 \%$ ) with those of the reference isolates of E. salmonicolor (CBS167.82, CBW810.85, and ITCCF283) sequenced in this study.

Inserting the LSU sequences determined in this study for the E. salmonicolor isolates into the data matrix used by Larsson et al. (12) yielded a total of 1,662 characters, of which 338 were parsimony informative. Heuristic searches produced 5,800 equally parsimonious trees (number of taxa $=184$ ) with consistency index $(\mathrm{CI})$ of 0.194 , retention index (RI) of 0.661 , and tree lengths of 3,516 steps. A strict consensus tree (Fig. 2) generated from the cladograms grouped the E. salmonicolor isolates within the corticioid clade.

Analyses of a smaller LSU data set containing a selection of isolates from each of the 12 groups identified by Larsson et al. (12) included 66 taxa and 1,662 characters. There were 797 characters included in the final analysis after exclusion of missing and ambiguous characters, of which 248 were parsimony informative. Heuristic searches produced one tree with a tree length of 1,600 steps, $\mathrm{CI}=0.318$, and RI = 0.585 (Fig. 3). E. salmonicolor isolates from South Africa grouped in a wellresolved clade together with the reference cultures of this fungus, separate from any of the other members of the Corticiaceae (Fig. 3). All of the 12 groups within the Homobasidiomycetes (12) could be distinguished on the cladogram.

The corticoid matrix included 819 characters after exclusion of missing data at the $5^{\prime}$ and $3^{\prime}$ ends of the sequences. The number of variable characters equaled 162 . The 
neighbor-joining tree generated from this data matrix grouped the three reference $E$. salmonicolor isolates, the isolate from Ethiopia, and the South African isolates in a highly supported (100\% bootstrap support) cluster. The Ethiopian and South African isolates formed a subcluster, indi- cating that they are more closely related to each other than to the other E. salmonicolor isolates (Fig. 4).

\section{DISCUSSION}

Other than preliminary reports $(20,21)$, this study represents the first report of pink disease on native South African tree species. Pink disease was first reported in South Africa in 1953 from exotic apple (Malus sp). trees (4). The fungus subsequently was isolated from two other exotic tree species $(14,19,20)$, but was not considered to be a serious disease of these trees.

\section{MP tree}

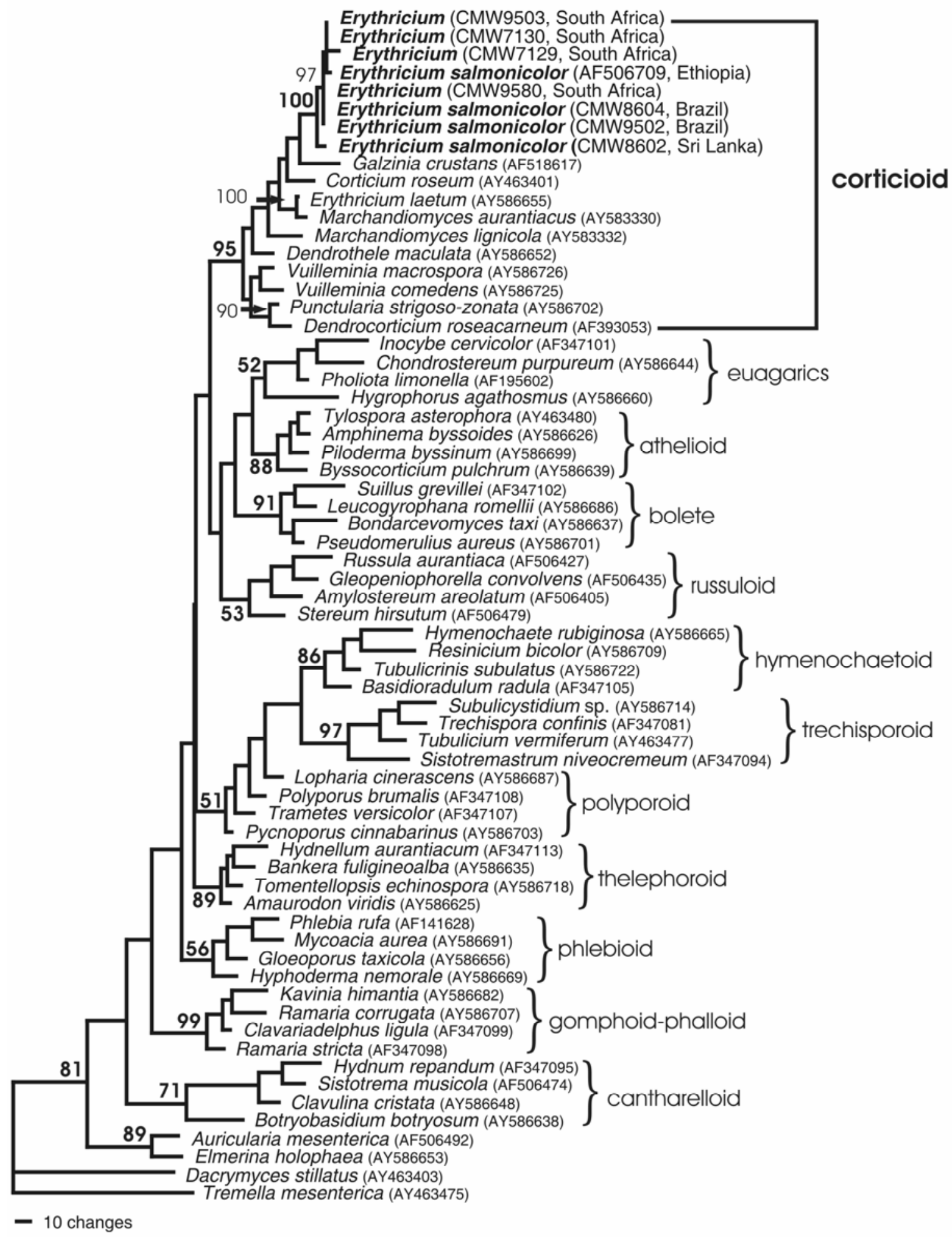

Fig. 3. Most parsimonious tree generated from a smaller data set that included all the species from the corticioid and representative species from the remaining groups in the Homobasidiomycetes. Bootstrap values (6) above 50\% are indicated on the branches. Clade names follow that of Larsson et al. (12). GenBank accession numbers are indicated next to the species names. 
Pink disease commonly was found on ornamental native tree species, where it caused branch and stem die-back. These trees include three of the four native Podocarpus spp. in South Africa. Although pink disease previously had been reported from Podocarpus spp., for example in India on Podocarpus gracilior Pilger (24), the severity of the disease and wide geographic distribution of affected trees in this genus in South Africa is of concern. Three $D$. cotinifolia trees with pink disease were also found in the Sabie area in close association with diseased Podocarpus trees. Furthermore, single trees of Maesa lanceolata and Ekebergia capensis, in a single garden, were identified with pink disease. This garden was in close proximity to a compartment of A. mearnsii which had, at the time, severe infection of Erythricium salmonicolor. All affected trees, except one Podocarpus tree, were found in disturbed areas such as gardens or plantations. This makes speculation as to the possible origin of the causal agent of pink disease difficult. Further surveys in undisturbed indigenous areas will be required to resolve this question more fully.

Pink disease was found in two geographically separated areas of South Africa. Both areas have high annual rainfall averages (above 1,500 mm). This agrees with reports that pink disease becomes increasingly damaging as the rainfall increases (24). Studies also have shown that E. salmonicolor requires $100 \%$ relative humidity for basidiospore germination (23). This correlation will help to focus future surveys for pink disease in South Africa because few places in the country has annual rainfall above $1,000 \mathrm{~mm}$ per annum.

To the best of our knowledge, results of this study represent the most comprehen- sive DNA sequence based comparisons of E. salmonicolor. E. salmonicolor traditionally has been classified within the Corticiaceae family (Aphyllophorales). The fungus was transferred from Corticium based on its large basidiospores and shortcelled subhymenial elements (2). Its placement in the Homobasidiomycetes has, however, been described as "uncertain" (8). Comparison of results generated from LSU DNA sequence data in this study with those from published data sets clearly support the separation of E. salmonicolor from fungi in the genera Corticium and Phanerochaete. Our results also suggest that E. laetum and E. salmonicolor represent separate genera. To our knowledge, there are only four species in the genus Erythricium, of which E. laetum has been described as the type $(2,5)$. The other two species are E. hypnophilum and $E$. chaparallum, for which no sequence data exists. It is clear that a further reevaluation of this genus is required and it should be considered that E. salmonicolor be described in a separate new genus.

Based on a limited number of E. salmonicolor isolates, it is clear that there are subdivisions within E. salmonicolor. Isolates from South Africa and Ethiopia grouped together in a subclade, separate from the isolates from South America and Asia. However, more isolates from other areas of the world are needed to clarify these subgroupings. It is clear that more research is needed to resolve the true position of this fungus.

The identification of pink disease from some of South Africa's best-known indigenous trees is of interest. It is unclear whether E. salmonicolor has been introduced into the country and subsequently has spread to indigenous trees, or whether

\section{NJ tree}

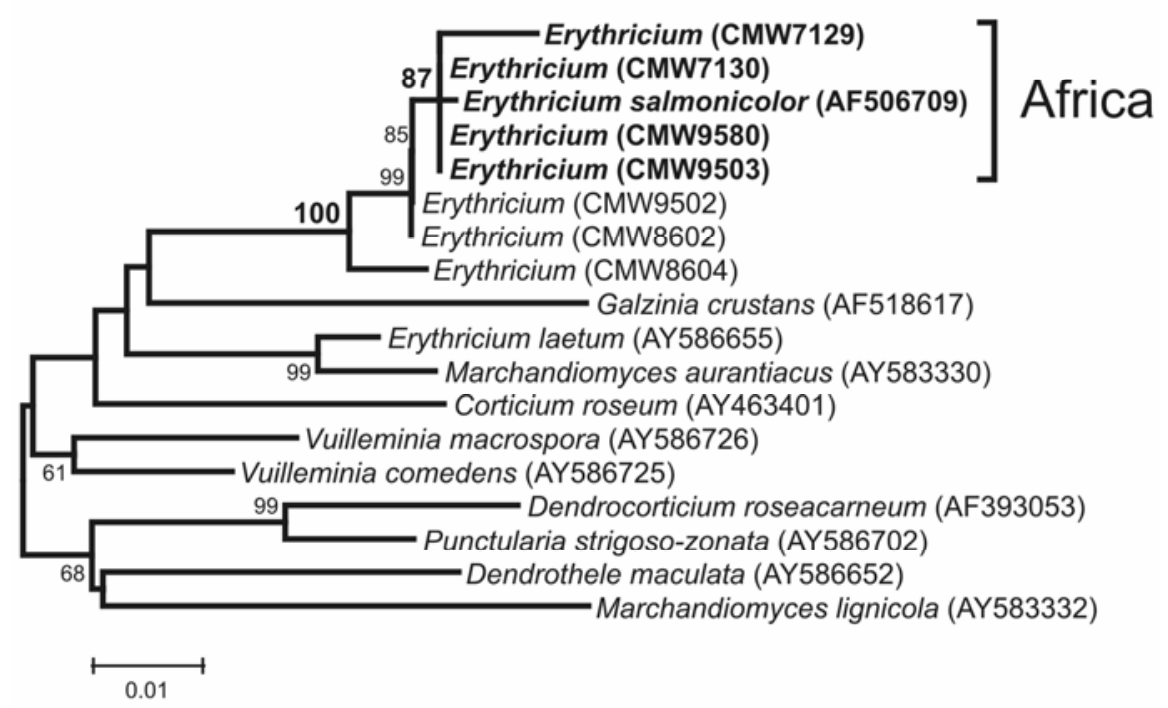

Fig. 4. Neighbor-joining tree based on large subunit DNA sequences from the species within the corticioid clade together with the Erythricium salmonicolor isolates included in this study. Bootstrap values (6) higher than $50 \%$ are indicated on the tree branches. Scale bar: 0.01 substitutions per site.

the fungus is native. In Kerala (India), the fungus is reported to occur commonly on native tree species in the low and medium altitude zones and to spread from the native hosts onto exotic Eucalyptus spp., resulting in disease epidemics $(22,24)$. $E$. salmonicolor now has been recorded on at least seven different tree families in South Africa, and several more elsewhere in the world. It is reasonable to suspect that the disease is more common in South Africa than is presently appreciated.

\section{ACKNOWLEDGMENTS}

We thank J. de Finn of Safcol for alerting us to this disease, A. v.d Hoef and P. Burdon for detecting other disease outbreaks and helping with the collection of samples, K.-H. Larsson for sharing the LSU data set with us, K. Nakasone for cultures and assistance in retrieving literature, and M. J. Wingfield for assistance with the manuscript.

\section{LITERATURE CITED}

1. Binder, M., and Hibbett, D. S. 2002. Higherlevel phylogenetic relationships of Homobasidiomycetes (mushroom-forming fungi) inferred from four rDNA regions. Mol. Phylogenet. Evol. 22:76-90

2. Burdsall, H. H., Jr. 1985. A contribution to the taxonomy of the genus Phanerochaete (Corticiaceae, Aphyllophorales). Mycol. Mem. 10. J. Cramer Publisher, Braunschweig, Germany.

3. Crous, P. W., Phillips, A. J. L., and Baxter, A. P. 2000. Phytopathogenic Fungi from South Africa. University of Stellenbosch, Department of Plant Pathology Press, University of Stellenbosch Printers, Stellenbosch, South Africa.

4. Doidge, E. M., Bottomley, A. M., van der Plank, J. E., and Pauer, G. D. 1953. A revised list of plant diseases in South Africa. Department of Agriculture, South Africa. Sci. Bull. No. 346.

5. Eriksson, J., and Ryvarden, L. 1975. The Corticiaceae of North Europe. Vol. 3. Fungifolora, Oslo, Norway.

6. Felsenstein, J. 1985. Confidence limits on phylogenies: An approach using the bootstrap. Evolution 39:783-791.

7. Hallenberg, N., and Parmasto, E. 1998. Phylogenetic studies in species of Corticiaceae growing on branches. Mycologia 90:640-654.

8. Hibbett, D. S., and Thorn, R. G. 2001. Basidiomycota: Homobasidiomycetes. Pages 121-168 in: The Mycota VII Part B, Systematics and Evolution. D. J. McLaughlin, E. G. McLaughlin, and P. A. Lemke, eds. SpringerVerlag, Berlin.

9. Hilton, R. N. 1958. Pink disease of Hevea caused by Corticium salmonicolor. J. Rubber Res. Inst. Malaysia 15:275-292.

10. Kimura, M. 1980. A simple method for estimating evolutionary rates of base substitutions through comparative studies of nucleotide sequences. J. Mol. Evol. 16:111-120.

11. Kumar, S., Tamura, K., Jakobsen, I. B., and Nei, M. 2001. MEGA2: Molecular Evolutionary Genetics Analysis software. Bioinformatics 17:1244-1245.

12. Larsson, K-H, Larsson, E., and Köljalg, U. 2004. High phylogenetic diversity among corticioid homobasidiomycetes. Mycol. Res. 108:983-1002.

13. Mohanan, C., and Sharma, J. K. 1989. Occurrence of new diseases of Casuarina equisetifolia. Indian For. 115:33-37.

14. Nicol, N., Kemp, G. H. J., and Wingfield, M. J. 1993. Corticium salmonicolor associated with a serious canker disease of Eucalyptus in South Africa. Phytophylactica 25:198.

15. Old, K. M., and Davison, E. M. 2000. Canker diseases of Eucalyptus. Pages 245-246 in: Dis- 
eases and Pathogens of Eucalypts. P. J. Keane, G. A. Kile, F. D. Podger, and B. N. Brown, eds. CSIRO Publishing, Collingwood, Australia.

16. Parmasto, E. 1995. Corticioid fungi: a cladistic study of a paraphyletic group. Can. J. Bot. 73(Suppl. 1):S843-S852.

17. Pradhanang, P. M. 1994. Pink disease (Corticium salmonicolor Berks \& Broome) control in mandarin orange (Citrus reticulata Blanco) by application of Bordeauz mixture. Crop Prot. 13:550-552.

18. Raeder, U., and Broda, P. 1985. Rapid preparation of DNA from filamentous fungi. Lett. Appl. Microbiol. 1:17-20.

19. Roberts, K. 1957. A list of fungi collected in wattle plantations. Rep. Wattle Res. Inst.
1956-1957:26-28.

20. Roux, J., Heath, R. N., Van der Hoef, A., and Wingfield, M. J. 2001. First report of pink disease on Eucalyptus and Podocarpus in South Africa. Joint Meeting of the American Phytopathological Society, Mycological Society of America and Society of Nematologists. Salt Lake City, Utah. (Abstr.) Phytopathology 91:S78.

21. Roux, J., Van der Hoef, A., and Wingfield, M. J. 2002. Pink disease of Eucalyptus and Podocarpus in South Africa. Proc. 40th Congr. South. Afr. Soc. Plant Pathol. Dikhololo, South Africa.

22. Sankaran, K. V., and Sharma, J. K. 1987. Three new hosts of pink disease caused by Corticium salmonicolor in Kerala. Indian J. For. 10:198 199.

23. Schneider-Christians, J., Fliege, F., and Schlösser, E. 1986. On the release, survival and importance of basidiospores of Corticium salmonicolor, the pathogen causing pink disease. J. Plant Dis. Prot. 93:397-403.

24. Seth, S. K., Bakshi, B. K., Reddy, M. A. R., and Sujan Singh. 1978. Pink disease of Euca lyptus in India. Eur. J. For. Pathol. 8:200-216.

25. Swofford, D.L. 1998. PAUP*. Phylogenetic Analysis using Parsimony (*and other meth ods). Version 4.0 beta version. Sinauer Associates, Sunderland, MA.

26. Worall, J. J. 1991. Media for selective isolation of hymenomycetes. Mycologia 83:296-302. 